\title{
Peramalan Jumlah Pengunjung Ciwangun Indah Camp Menggunakan Metode Moving Average dan Exponential Smoothing
}

\author{
Jordi Rachmat Hakeem ${ }^{1}$ \& Rahmat Priyanto ${ }^{2}$ \\ ${ }^{1}$ STP Ars Internasional, jordih37@gmail.com \\ ${ }^{2}$ STP Ars Internasional, rahmat.rmp@bsi.ac.id
}

\begin{abstract}
ABSTRAK
Peramalan adalah upaya memprediksi peristiwa pada masa yang akan datang menggunakan data masa lalu. Belum diterapkannya teknik peramalan pada Ciwangun Indah Camp seringkali menyebabkan pihak destinasi wisata mengalami kesulitan dalam proses penyusunan rencana kerja maupun penentuan persediaan fasilitas yang disewakan pihak destinasi wisata, terutama dengan jumlah pengunjung Ciwangun Indah Camp yang tidak menentu setiap tahunya. Penerapan peramalan pengunjung pada Ciwangun Indah Camp diharapkan dapat menjadi dasar penyusunan rencana maupun sebagai alat yang mempermudah proses pengambilan keputusan bagi pihak destinasi wisata. Penelitian ini bertujuan untuk mengetahui peramalan pengunjung Ciwangun Indah Camp dengan metode Moving Average dan Exponential Smoothing dan metode peramalan yang tepat untuk diterapkan pada Ciwangun Indah Camp. Metode penelitian yang digunakan dalam penelitian ini adalah deskriptif dan komparatif dengan pendekatan kualitatif. Pengambilan data dilakukan melalui observasi secara langsung dilapangan, kegiatan wawancara, studi kepustakaan, serta data masa lalu jumlah pengunjung Ciwangun Indah Camp. Hasil penelitian ini menunjukan bahwa metode Exponential Smoothing adalah metode peramalan yang paling tepat untuk diterapkan di Ciwangun Indah Camp.
\end{abstract}

Kata Kunci: Peramalan, Moving Average, Exponential Smoothing

ABSTRACT

Forecasting is an attempt to predict future events using past data. The absence of forecasting techniques at Ciwangun Indah Camp often causes tourist destinations to experience difficulties in the process of preparing work plans and determining the supply of facilities rented by tourist destinations, especially with uncertain numbers of Ciwangun Indah Camp visitors every year. The application of visitor forecasting at Ciwangun Indah Camp is expected to be the basis for planning and as a tool to facilitate the decision making process for tourist destinations. This study aims to determine the forecasting of Ciwangun Indah Camp visitors with the Moving Average and Exponential Smoothing methods and the proper forecasting method to be applied in Ciwangun Indah Camp. The research method used in this study is descriptive and comparative with a qualitative approach. Data collection is done through by direct observation in the field, interview activities, literature study, and past data on the number of visitors in Ciwangun Indah Camp. The results of this study indicate that the Exponential Smoothing method is the most appropriate forecasting method to be implemented in Ciwangun Indah Camp.

Keywords: Forecasting, Moving Average, Exponential Smooothing

Diterima: 11 September 2018, Direvisi: 15 Oktober 2018, Diterbitkan: 15 Februari 2019

PENDAHULUAN

Ciwangun Indah Camp adalah suatu destinasi wisata yang terletak di Kabupaten Bandung Barat, dimana produk wisata yang ditawarkan diantaranya : Shaking Bridge, Flying Fox, Tree In One, Paint Ball, Air Soft Gun, Wisata berkuda dan lain sebagainya (Marketing Ciwangun Indah Camp 2018). Aktivitas wisata yang disediakan pengelola Ciwangun Indah Camp memiliki daya tarik tersendiri bagi wisatawan yang berkunjung, dimana atraksi wisata di alam menjadi keunikan dan keunggulan dari produk wisata yang ditawarkan.

Pengembangan produk wisata terus dilakukan oleh pihak pengelola wisata, tetapi hal tersebut belum memberikan dampak yang signifikan terhadap 
peningkatan jumlah kunjungan wisatawan ke destiansi wisata. Dimana data kunjungan wisatawan ke Ciwangun Indah Camp mengalami

fluktuatif setiap tahunya. Data kunjungan wisatawan selengkapnya dapat dilihat pada tabel sebagai berikut:

Tabel 1. Data Jumlah Pengunjung Reguler Ciwangun Indah Camp 2013-2017

\begin{tabular}{|l|c|c|c|c|c|}
\hline \multirow{2}{*}{ Bulan } & \multicolumn{5}{|c|}{ Tahun } \\
\cline { 2 - 6 } & $\mathbf{2 0 1 3}$ & $\mathbf{2 0 1 4}$ & $\mathbf{2 0 1 5}$ & $\mathbf{2 0 1 6}$ & $\mathbf{2 0 1 7}$ \\
\hline Januari & 6.721 & 3.905 & 4.011 & 3.544 & 3.715 \\
\hline Februari & 6.511 & 1.878 & 2.143 & 1.867 & 2.233 \\
\hline Maret & 5.901 & 3.927 & 2.173 & 2.157 & 1.771 \\
\hline April & 6.091 & 3.011 & 1.750 & 1.975 & 2.247 \\
\hline Mei & 4.872 & 3.497 & 3.463 & 1.723 & 2.026 \\
\hline Juni & 5.697 & 2.571 & 1.719 & 1.512 & 2.689 \\
\hline Juli & 7.009 & 3.169 & 6.372 & 6.724 & 3.964 \\
\hline Agustus & 5.619 & 3.335 & 2.965 & 3.011 & 1.561 \\
\hline September & 8.712 & 2.399 & 2.728 & 2.901 & 3.021 \\
\hline Oktober & 5.123 & 1.847 & 2.300 & 2.631 & 3.123 \\
\hline November & 4.124 & 2.132 & 2.068 & 2.152 & 3.875 \\
\hline Desember & 3.997 & 2.994 & 3.885 & 4.011 & 4.902 \\
\hline Jumlah & $\mathbf{7 0 . 3 7 7}$ & $\mathbf{3 4 . 6 6 5}$ & $\mathbf{3 5 . 0 7 7}$ & $\mathbf{3 4 . 2 0 8}$ & $\mathbf{3 5 . 1 2 7}$ \\
\hline
\end{tabular}

Sumber : Marketing Ciwangun Indah Camp (2018)

Berdasarkan data pada Tabel 1, tingkat kunjungan wisatawan ke Ciwangun Indah Camp mengalami flukiatif setiap tahunya. Jumlah kunjungan tertinggi terjadi pada tahun 2013, kemudian mengalami penurunan di tahun 2014, sedangkan tahun 2015 sampai 2017 jumlah kunjungan wisatawan naik turun.

Terkait dengan relasi antara potensi destinasi wisata yang baik dengan tingkat kunjungan wisatawan yang tidak menentu maka pihak pengelola wisata harus mampu memprediksi tingkat kunjungan yang akan datang, hal tersebut sebagai dasar dalam merumuskan rencana strategi dalam meningkatkan jumlah kunjungan pada periode yang akan datag, baik dalam aspek peningkatan fasilitas maupun pelayananya. Untuk dapat mengetahui seberapa banyak jumlah pengunjung yang akan datang, maka harus dilakukan terlebih dahulu analisis prediksi oleh pihak pengelola Ciwangun Indah Camp. Analisis tersebut dapat dilakukan melalui suatu metode yang disebut "Peramalan (Forecast)".

Berdasarkan hasil wawancara yang dilakukan dengan pihak pengelola wisata, Ciwangun Indah Camp belum menggunakan metode peramalan pengunjung, sehingga selama ini dalam permasalahan peramalan jumlah kunjungan yang dilakukan oleh pengelola hanya berdasarkan prediksi dan pengalaman-pengalaman saja. Keuntungan yang dapat diperoleh dengan menggunakan peramalan pengunjung maka akan diketahui besarnya fluktuasi dan dianggap mampu untuk dijadikan dasar dalam pembuatan strategi penetapan target jumlah pengunjung yang akan datang. Dengan peramalan pula pihak pengelola destinasi wisata dapat membuat program atau promosi wisata pada saat terjadinya penurunan pengunjung. Demikian juga pada saat terjadi peningkatan jumlah pengunjung pihak destinasi wisata dapat menggunakan peramalan sebagai dasar pengambilan keputusan mengenai penetapan persediaan jumlah produk wisata seperti peralatan dan keperluan untuk berkemah untuk disewakan kepada wisatawan yang berkunjung.

Penyesuaian persediaan produk wisata dengan tingkat pengunjung ini juga merupakan sebuah langkah antisipasi dalam mengatasi permintaan akan produk wisata tersebut yang seringkali tidak terpenuhi. Peramalan dapat pula dijadikan sebagai alat penentuan kelangsungan pengembangan sebuah program wisata untuk periode selanjutnya. Selain itu penetapan target jumlah pengunjung yang tepat melalui peramalan juga dapat dijadikan sebagai evaluasi bagi Ciwangun Indah Camp dalam meningkatkan pelayanannya kepada pengunjung. Dalam menghadapi iklim persaingan bisnis pariwisata yang semakin kompetitif, peramalan merupakan salah satu alat bantu dalam proses pengambilan keputusan yang dibutuhkan pihak destinasi wisata dalam penentuan strategi yang digunakan. Apabila pengelola destinasi wisata Ciwangun Indah Camp tidak dapat mempersiapkan diri dengan baik untuk menghadapi tantangan persaingan bisnis pariwisata saat ini, dikhawatirkan produk-produk wisatanya tidak mampu bertahan dalam menghadapi keadaan pengunjung yang tidak menentu, sehingga akan berdampak pada kelangsungan di masa yang akan datang. 
Kesesuaian jumlah persediaan produk wisata sangat penting bagi pihak destinasi wisata karena kekurangan produk wisata akan menyebabkan permintaan pengunjung tidak terpenuhi sedangkan apabila persediaan produk wisata berlebih akan menyebabkan pihak destinasi wisata banyak mengeluarkan biaya perawatan produk wisata, karena terlalu lama disimpan. Tidak adanya peramalan di Ciwangun Indah Camp juga sering menyebabkan terhambatnya penyusunan jadwal pekerjaan, maupun perekrutan tenaga kerja lepas (freelance) karena peningkatan jumlah pengunjung yang tidak terduga. Oleh karena itu maka teknik peramalan dapat menjadii suatu cara dalam memaksimalkan berbagai aspek yang dimiliki oleh pengelola wisata dalam meningkatkan kepuasan dan jumlah kunjungan wisatawan.

Teknik peramalan dapat dilakukan dengan memprediksi seberapa banyak jumlah pengunjung Ciwangun Indah Camp dimasa yang akan datang, dimana penggunaan teknik dalam meramalkan tingkat kunjungan dapat dilakukan dengan berbagai alat analisis, diantaranya adalah Moving Average dan Exponential Smoothing. Teknik analisis peramalan Moving Average menggunakan data kunjungan wisatawan per 3 bulan dalam satu tahun untuk perhitunganya, sedangkan Exponential Smoothing menggunakan data kunjungan wisatawan per tahun. Landasan dalam penggunaan kedua alat analisis tersebut adalah sebagai upaya dalam membandingkan alat analisis mana apa yang paling tepat untuk diterapkan di Ciwangun Indah Camp. Selain itu penggunaan analisis mode Moving Average dan Exponential Smoothing relative mudah digunakan dan dipahami, sehingga pengaplikasianya tidak membutuhkan waktu dan biaya yang banyak. Penggunaan teknik peramalan Moving Average dan Exponential Smoothing di Ciwangun Indah Camp diharapkan mampu memberikan dampak yang signifikan dalam merumuskan rencana startegi perusahaan dalam mempredikasi dan meningkatkan jumlah kunjungan wisatawan kedepanya. Berdasarkan latar belakang yang telah diuraikan, maka judul penelitian yang diambil adalah "Peramalan Jumlah Pengunjung Ciwangun Indah Camp Dengan Metode Moving Average Dan Exponential Smoothing”.

\section{KAJIAN LITERATUR}

Peramalan sebagai perkiraan yang ilmiah (educated guess)". Karenanya, "setiap pengambilan keputusan yang menyangkut keadaan pada masa yang akan datang, pasti ada peramalan yang melandasi pengambilan keputusan tersebut" (Rusdiana, 2014). Oleh karena itu landasan yang digunakan didalam menentukan sebuah keputusan harus memiliki dasar yang kuat keputusan tersebut tepat dan dapat dipertanggungjawabkan. Salah satunya diantaranya dapat dilakukan melalui peramalan, yaitu memprediksi kejadian dimasa yang akan datang sehingga dapat dijadikan sebagai bahan pertimbangan dalam proses pengambilan keputusan. Peramalan menjadi salah satu hal yang penting dalam pengambilan keputusan perusahaan. Hal ini dikarenakan keefektifan sebuah keputusan tergantung pada deretan kejadian yang diakibatkan keputusan tersebut" (Syahputra et all , 2018)

Adapun tujuan peramalan menurut Sofyan (2013) "tujuan utama peramalan adalah untuk meramalkan permintaan dimasa yang akan datang, sehingga diperoleh suatu perkiraan yang mendekati keadaan yang sebenarnya.peramalan tidak akan pernah sempurna, tetapi meskipun demikian hasil peramalan akan memberikan arahan bagi suatu perencanaan".

Suatu perusahaan biasanya menggunakan prosedur peramalan yaitu diawali dengan melakukan peramalan lingkungan, diikuti dengan peramalan penjualan pada organisasi dan diakhiri dengan peramalan permintaan pasar. Kegiatan peramalan dapat dilakukan dengan berbagai metode analisis, diantaranya adalah metode analisis Moving Average dan Exponential Smoothing. Moving Average menurut Heizer \& Render (2015), adalah sebuah metode peramalan yang menggunakan rata-rata dari data aktual periode sebelumnya untuk meramalkan periode selanjutnya". Metode ini disebut rata - rata bergerak karena setiap kali data aktual baru tersedia, maka data paling awal atau terdahulu diganti dengan data baru, lalu dihitung dan hasilnya digunakan sebagai ramalan permintaan untuk periode yang akan datang. Tujuan utama dari penggunaan rata - rata bergerak adalah untuk menghilangkan atau mengurangi variasi acak permintaan dalam hubungannya dengan waktu. Peramalan rata - rata bergerak (Moving Average) menggunakan sejumlah data aktual masa lalu untuk menghasilkan peramalan. Rata - rata bergerak berguna jika mengasumsikan bahwa 
permintaan pasar akan stabil sepanjang masa yang kita ramalkan (Heizer \& Render, 2009)".

Secara sistematis, rata - rata bergerak sederhana ditunjukan sebagai berikut :

$$
\begin{aligned}
& \quad \mathrm{MA}_{\mathrm{n}}=\frac{\sum \text { Permintaan dalam } \mathrm{n} \text { Periode Sebelumnya }}{\mathrm{n}} \\
& \text { Dimana } \\
& \mathrm{n}=\text { jumlah periode dalam rata - rata bergerak }
\end{aligned}
$$

Adapun metode analisis peramalan Exponential Smoothing atau penghalusan eksponensial adalah metode peramalan pergerakan rata-rata bobot lainnya , dimana poin-poin data ditimbang oleh sebuah fungsi eksponensial". Metode ini lebih cocok digunakan untuk pola data yang tidak stabil atau terjadi perubahan data yang besar dan bergejolak. Dimana $\alpha$ adalah bobot, atau penghalusan konstan (smoothing constant) yang memiliki nilai lebih tinggi daripada atau setara dengan 0 dan kurang dari atau setara dengan 1(Heizer \& Render, 2015). Rumus dari metode Exponential Smoothing adalah sebagai berikut : $\mathrm{Ft}=$ Peramalan periode sebelumnya $+\alpha$

(Permintaan aktual periode sebelumnya Peramalan periode sebelumnya )

Dimana :

$$
\mathrm{Ft}=\mathrm{Ft}-1+\alpha(\mathrm{At}-1-\mathrm{Ft}-1)
$$

$\mathrm{Ft}=$ peramalan baru

Ft-1 = peramalan sebelumnya

$\alpha=$ konstanta penghalusan

At-1 $=$ permintaan aktual periode lalu

\section{METODOLOGI}

Jenis penelitian yang digunakan dalam penelitian ini adalah analisis deskriptif dan komparatif dengan pendekatan yang digunakan secara kualitatif. Penelitian dilakukan di Destinasi Wisata Ciwangun Indah Camp. Penelitian ini menggunakan dua sumber data yaitu, data primer dan data sekunder. Data primer adalah sumber data yang langsung memberikan data kepada pengumpul data. Sumber data primer diperoleh secara langsung dari pihak pengelola Ciwangun Indah Camp. Selain itu diperoleh data berupa lisan dan tulisan, data-data tersebut diperoleh melalui kegiatan observasi lapangan dan wawancara dengan pihak pengelola Ciwangun Indah Camp. Data sekunder adalah sumber data yang tidak langsung memberikan data kepada pengumpul data, misalnya dari literatur, hasil penelitian ,website ,buku, lewat dokumen dan sumbersumber yang tidak langsung lainnya yang berkaitan dengan permasalahan yang diteliti.
Teknik pengumpulan data penelitian ini dilakukan melalui observasi lapangan, wawancara, penelitian kepustakaan dan dokumentasi.

Penelitian dilakukan dengan dengan menggunakan 2 metode peramalan, metode peramalan yang pertama menggunakan metode Moving Average dan metode peramalan yang kedua menggunakan Exponential Smoothing. Ini bertujuan untuk mengetahui peramalan pengunjung Ciwangun Indah Camp dengan metode Moving Average dan Exponential Smoothing dan metode peramalan yang tepat untuk diterapkan pada Ciwangun Indah Camp. Peramalan ini menggunakan data berdasarkan pada jumlah kunjungan Ciwangun Indah Camp pada periode 2016-2017. Metode selanjutnya digunakan uji kesalahan peramalan dengan menggunakan MAD (Mean Absolute Deviation), MSE (Mean Square Error) dan MAPE (Mean Percentage Average Error). Uji kesalahan peramalan ini bertujuan untuk mengetahui tingkat kesalahan dalam masing-masing metode peramalan yang digunakan.

\section{HASIL DAN PEMBAHASAN Deskripsi Wisatawan}

Deskripsi wisatawan dapat menggambarkan minat dan ketertarikan wisatawan akan sebuah destinasi wisata. Terdapat berbagai Deskripsi wisatawan baik dari segi demografi maupun psikografi, beberapa Deskripsi yang akan peneliti bahas dalam penelitian ini adalah Deskripsi wisatawan berdasarkan Jenis Kelamin, Usia dan Tingkat Ekonomi.

Deskripsi pertama yaitu Jenis Kelamin merupakan salah satu Deskripsi yang sangat cocok digunakan dalam menentukan Deskripsi pengunjung Ciwangun Indah Camp, hal ini karena berbagai aktivitas yang ada di Ciwangun Indah Camp sangat menarik untuk dinikmati oleh semua wisatawan baik perempuan maupun laki - laki. Berdasarkan wawancara yang telah peneliti lakukan dengan ketiga informan yang merupakan pihak pengelola Ciwangun Indah Camp dan merupakan narasumber yang sering berinteraksi dengan pengunjung mereka menyimpulkan bahwa frekuensi kedatangan wisatawan Laki-laki maupun Wisatawan Perempuan berada pada jumlah yang sama dalam mengunjungi dan menikmati indahnya Ciwangun Indah Camp. Hal ini sejalan dengan hasil observasi yang peneliti lakukan, selama berada disana. Terdapatnya berbagai kegiatan yang memacu adrenalin dan 
beberapa aktivitas yang sangat disukai para pecinta alam yang kebanyakan berjenis kelamin laki-laki, seperti hiking dan berkemah juga disediakan di kawasan wisata ini, jalur pendakian yang sudah dibuat lebih nyaman oleh pihak pengelola namun tetap mempertahankan konsep alaminya tidak akan mengurangi rasa wisatawan tetap berada dialam, hal inilah yang semakin menarik wisatawan untuk berkunjung.

Bagi wisatawan perempuan pemandangan yang indah, udara sejuk dan beberapa spot bagus untuk berfoto seperti curug atau air terjun sangat berpengaruh terhadap minat wisatawan dalam berkunjung. Selain kedalaman curug yang tidak terlalu dalam sehingga pengunjung diizinkan untuk berenang disekitarnya hal tersebut menambah ketertarikan pengunjung akan tempat ini, khususnya wisatawan perempuan yang sangat menyukai berfoto.

Deskripsi wisatawan yang kedua yaitu usia merupakan Deskripsi yang cocok untuk digunakan dalam mengukur Deskripsi wisatawan yang mengunjungi Ciwangun Indah Camp. Dilihat dari jenis wisata yang termasuk kedalam wisata alam tentu Ciwangun Indah Camp memiliki berbagai ilmu mengenai alam. Berdasarkan wawancara yang peneliti lakukan dengan ketiga informan yang merupakan pihak pengelola Ciwangun Indah Camp dan merupakan narasumber yang sering berinteraksi dengan pengunjung mereka menyimpulkan bahwa kawasan wisata Ciwangun Indah Camp ini mayoritas dikunjungi oleh pengunjung dari kalangan remaja dan beberapa perusahaan besar. Hal ini sejalan dengan observasi yang peneliti lakukan selama melakukan penelitian disana. Kegiatan yang mereka lakukan bermacam-macam mulai dari yang datang untuk sekedar menikmati berbagai permainan yang menantang adrenalin disini, hingga yang membuat reservasi untuk menjalankan kegiatan sekolah seperti masa orientasi mahasiswa. Ditambah dengan trend yang sedang berjalan saat ini yaitu media sosial dan fenomena selfie maupun wefie yang tentu sangat berpengaruh terhadap tujuan remaja dalam berwisata tidak hanya untuk mengunjungi sebuah tempat wisata namun juga sebagai ajang untuk menunjukan eksistensi dirinya yang dituangkan

Tabel 2. Peramalan Pengunjung Ciwangun Indah Camp Dengan Metode Moving Average 3

Bulanan Tahun 2016

\begin{tabular}{|c|c|c|}
\hline Bulan & $\begin{array}{c}\text { Data Pengunjung } \\
\text { Aktual }\left(\boldsymbol{A}_{\boldsymbol{t}}\right)\end{array}$ & $\begin{array}{c}\text { Peramalan }\left(\boldsymbol{F}_{\boldsymbol{t}}\right) \text { 3 Bulanan } \\
(\text { Moving Average }-3)\end{array}$ \\
\hline Oktober 2015 & 2300 & - \\
\hline
\end{tabular}

dalam bentuk sebuah foto kemudian dikirimkan melalui media sosial yang dimiliki. Trend tersebut tentu sangat mempengaruhi pilihan remaja sekarang dalam berwisata termasuk dalam mengunjungi Ciwangun Indah Camp, beberapa objek yang indah seperti Curug Tilu atau Air Terjun sangat diminati oleh wisatawan remaja saat ini.

Deskripsi wisatawan yang ketiga yaitu tingkat ekonomi merupakan Deskripsi yang dapat digunakan oleh pihak Ciwangun Indah Camp dalam memperkirakan kemampuan pengunjungnya.

Berdasarkan wawancara yang peneliti lakukan dengan ketiga informan yang merupakan pihak pengelola Ciwangun Indah Camp dan merupakan narasumber yang sering berinteraksi dengan pengunjung mereka menyimpulkan bahwa pengunjung yang datang ke kawasan wisata Ciwangun Indah Camp adalah pengunjung yang memiliki tingkat ekonomi menengah kebawah.

Hal ini dikarenakan harga tiket masuk kawasan wisata ini yang sangat murah dan terjangkau oleh seluruh kalangan masyarakat. Selain itu berdasarkan observasi yang peneliti lakukan terdapat berbagai paket wisata seperti paket outbond berikut berbagai tarifnya yang dapat dinikmati oleh pengunjung. Ciwangun Indah Camp membebaskan pengunjung dalam memilih berbagai aktivitas yang ada mulai dari persatuan aktivitas hingga beberapa aktivitas dalam bentuk paket. Kelebihan dari adanya paket wisata ini adalah pengunjung dapat menikmati lebih banyak aktivitas wisata dengan harga yang lebih murah, dengan harga paket mulai dari Rp.60.000 hingga Rp.400.000 maka Ciwangun Indah Camp merupakan kawasan wisata yang cocok untuk masyarakat menengah kebawah.

Hasil analisis peramalan metode analisis Moving Average 3 bulanan menggunakan data kunjungan wisatawan tahun 2016 di Ciwangun Indah Camp yang secara lengkap dapat dilihat pada tabel sebagai berikut:

\section{Perhitungan Peramalan dengan Metode Moving Average 3 Bulanan}




\begin{tabular}{|l|c|c|}
\hline November 2015 & 2068 & - \\
\hline Desember 2015 & 3885 & - \\
\hline Januari 2016 & 3544 & 2751 \\
\hline Februari 2016 & 1867 & 3166 \\
\hline Maret 2016 & 2157 & 3099 \\
\hline April 2016 & 1975 & 2523 \\
\hline Mei 2016 & 1723 & 2000 \\
\hline Juni 2016 & 1512 & 1952 \\
\hline Juli 2016 & 6724 & 1736 \\
\hline Agustus 2016 & 3011 & 3320 \\
\hline September 2016 & 2901 & 3749 \\
\hline Oktober 2016 & 2631 & 4212 \\
\hline November 2016 & 2152 & 2848 \\
\hline Desember 2016 & 4011 & 2561 \\
\hline Total Peramalan Pengunjung Tahun 2016 & 33917 \\
\hline \multicolumn{2}{|l}{ Rata - rata Peramalan Pengunjung Perbulan Tahun 2016 } & 2826 \\
\hline
\end{tabular}

Sumber: Hasil Pengolahan Data (2018)

Keterangan : Nilai peramalan adalah hasil pembulatan

Berdasarkan Tabel 2 yang merupakan hasil perhitungan peramalan pengunjung Ciwangun Indah Camp pada tahun 2016 dengan metode Moving Average maka diperoleh hasil peramalan rata rata pengunjung perbulan dalam satu tahun sebesar 2772 orang. Selain itu dapat dilihat jumlah pengunjung terbesar terdapat pada bulan Oktober sebesar 3995 orang. Sedangkan jumlah pengunjung terendah terdapat pada bulan Juli sebesar 1736 0rang.

Selanjutnya adalah Hasil analisis peramalan metode analisis Moving Average 3 bulanan menggunakan data kunjungan wisatawan tahun 2017 di Ciwangun Indah Camp yang secara lengkap dapat dilihat pada tabel sebagai berikut:

Tabel 3. Peramalan Pengunjung Ciwangun Indah Camp Dengan Metode Moving Average 3

Bulanan Tahun 2017

\begin{tabular}{|l|c|c|}
\hline Bulan & $\begin{array}{c}\text { Data Pengunjung } \\
\text { Aktual }\left(\boldsymbol{A}_{\boldsymbol{t}}\right)\end{array}$ & $\begin{array}{c}\text { Peramalan }\left(\boldsymbol{F}_{\boldsymbol{t}}\right) \text { 3 Bulanan } \\
\text { (Moving Average - 3) }\end{array}$ \\
\hline Oktober 2016 & 2631 & - \\
\hline November 2016 & 2152 & - \\
\hline Desember 2016 & 4011 & 2931 \\
\hline Januari 2017 & 3715 & 3293 \\
\hline Februari 2017 & 2233 & 3320 \\
\hline Maret 2017 & 1771 & 2573 \\
\hline April 2017 & 2247 & 2084 \\
\hline Mei 2017 & 2026 & 2081 \\
\hline Juni 2017 & 2689 & 2321 \\
\hline Juli 2017 & 3964 & 2893 \\
\hline Agustus 2017 & 1561 & 2738 \\
\hline September 2017 & 3021 & 2849 \\
\hline Oktober 2017 & 3123 & 2568 \\
\hline November 2017 & 3875 & 3340 \\
\hline Desember 2017 & 4902 & 32991 \\
\hline Total Peramalan Pengunjung Tahun 2017 & 2750 \\
\hline $\begin{array}{l}\text { Rata - rata Peramalan Pengunjung Perbulan } \\
\text { Tahun 2017 }\end{array}$ & \\
\hline
\end{tabular}

Sumber: Hasil Pengolahan Data (2018)

Keterangan : Nilai peramalan adalah hasil pembulatan

Berdasarkan Tabel 3 yang merupakan hasil perhitungan peramalan pengunjung Ciwangun Indah Camp pada tahun 2017 dengan metode
Moving Average maka diperoleh hasil peramalan rata rata pengunjung perbulan dalam satu tahun sebesar 2750 orang. Selain itu dapat dilihat 
jumlah pengunjung terbesar terdapat pada bulan Oktober sebesar 3340 orang. Sedangkan jumlah pengunjung terendah terdapat pada bulan Juli sebesar 2081 orang.

\section{Perhitungan Peramalan dengan Metode} Exponential Smoothing

Tabel 4. Peramalan Pengunjung Ciwangun Indah Camp

Dengan Metode Pemulusan Exponential $\alpha=0,15$ Tahun 2016

\begin{tabular}{|c|c|c|c|}
\hline Bulan & Indeks & Data Pengunjung Aktual $\left(\boldsymbol{A}_{t}\right.$ & $\begin{array}{c}\text { Peramalan }\left(\boldsymbol{F}_{\boldsymbol{t}}\right) \text { Exponential } \\
\text { Smoothing }\end{array}$ \\
\hline Januari & 1 & & 2851 \\
\hline Februari & 2 & 3544 & 2955 \\
\hline Maret & 3 & 1867 & 2792 \\
\hline April & 4 & 2157 & 2697 \\
\hline Mei & 5 & 1975 & 2589 \\
\hline Juni & 6 & 1723 & 2466 \\
\hline Juli & 7 & 1512 & 2323 \\
\hline Agustus & 8 & 6724 & 2983 \\
\hline September & 9 & 3011 & 2942 \\
\hline Oktober & 10 & 2901 & 2936 \\
\hline November & 11 & 2631 & 2779 \\
\hline \multicolumn{2}{|c|}{12} & 2152 & 33203 \\
\hline
\end{tabular}

Sumber: Hasil Pengolahan Data (2018)

Keterangan : Nilai peramalan adalah hasil pembulatan

Berdasarkan Tabel 4 yang merupakan hasil perhitungan peramalan pengunjung Ciwangun Indah Camp pada tahun 2016 dengan metode Exponential Smoothing maka diperoleh hasil peramalan rata rata pengunjung perbulan dalam satu tahun sebesar 2749 orang. Selain itu dapat dilihat jumlah pengunjung terbesar terdapat pada bulan Februari sebesar 2955 orang. Sedangkan

jumlah pengunjung terendah terdapat pada bulan Juli sebesar 2323 Orang.

Selanjutnya adalah Hasil analisis peramalan metode analisis Exponential Smoothing menggunakan data kunjungan wisatawan tahun 2017 di Ciwangun Indah Camp yang secara lengkap dapat dilihat pada tabel sebagai berikut:

Tabel 5. Peramalan Pengunjung Ciwangun Indah Camp

Dengan Metode Pemulusan Exponential $\alpha=0,15$ Tahun 2017

\begin{tabular}{|c|c|c|c|}
\hline Bulan & Indeks & $\begin{array}{c}\text { Data Pengunjung Aktual } \\
\left(\boldsymbol{A}_{\boldsymbol{t}}\right)\end{array}$ & Peramalan $\left(\boldsymbol{F}_{\boldsymbol{t}}\right)$ Exponential Smoothing \\
\hline Januari & 1 & 3715 & 2927 \\
\hline Februari & 2 & 2233 & 3045 \\
\hline Maret & 3 & 1771 & 2923 \\
\hline April & 4 & 2247 & 2750 \\
\hline Mei & 5 & 2026 & 2675 \\
\hline Juni & 6 & 2689 & 2578 \\
\hline Juli & 7 & 3964 & 2595 \\
\hline Agustus & 8 & 1561 & 2800 \\
\hline September & 9 & 3021 & 2614 \\
\hline Oktober & 10 & 3123 & 2675 \\
\hline November & 11 & 3875 & 2742 \\
\hline Desember & 12 & 4902 & 2912 \\
\hline
\end{tabular}




\begin{tabular}{|l|c|}
\hline Total Peramalan Pengunjung Tahun 2017 & 33236 \\
\hline Rata - rata Peramalan Pengunjung Perbulan Tahun 2017 & 2770 \\
\hline
\end{tabular}

Sumber: Hasil Pengolahan Data (2018)

Keterangan : Nilai peramalan adalah hasil pembulatan

Berdasarkan Tabel 5 yang merupakan hasil perhitungan peramalan pengunjung Ciwangun Indah Camp pada tahun 2017 dengan metode Exponential Smoothing maka diperoleh hasil peramalan rata rata pengunjung perbulan dalam satu tahun sebesar 2770 orang. Selain itu dapat dilihat jumlah pengunjung tertinggi terdapat pada bulan Februari sebesar 3045 orang. Sedangkan jumlah pengunjung terendah terdapat pada bulan Juli sebesar 2578 0rang.

\section{Uji Kesalahan Peramalan}

Dalam kegiatan peramalan terdapat presentase kesalahan dari setiap metode analisis yang digunakan, dimana tingkat kesalahan tersebut sebagai perbandingan dalam pengujian alat analisis mana yang paling tepat untuk dgunakan di Ciwangun Indah Camp.

Berikut ini adalah hasil uji kesalahan metode analisis Moving Average 3 bulanan menggunakan data kunjungan wisatawan ke Ciwangun Indah Camp tahun 2016 yang secara lengkap dapat dilihat pada tabel sebagai berikut:

Tabel 6. Uji Kesalahan Peramalan Pegunjung Ciwangun Indah Camp Menggunakan Metode Moving Average 3 Bulanan Tahun 2016

\begin{tabular}{|c|c|c|c|c|c|c|}
\hline Bulan & \begin{tabular}{c|} 
Hasil \\
Peramalan
\end{tabular} & \begin{tabular}{c|} 
Jumlah \\
Pengunjung
\end{tabular} & $\mathbf{A E}$ & MAD & MSE & $\begin{array}{c}\text { MAPE } \\
\text { (\%) }\end{array}$ \\
\hline Januari & 2.751 & 3.544 & -793 & 793 & 628849 & 29 \\
\hline Februari & 3.166 & 1.867 & 1.299 & 1299 & 1687401 & 41 \\
\hline Maret & 3.099 & 2.157 & 942 & 942 & 887364 & 30 \\
\hline April & 2.523 & 1.975 & 548 & 548 & 300304 & 22 \\
\hline Mei & 2.000 & 1.723 & 277 & 277 & 76729 & 14 \\
\hline Juni & 1.952 & 1.512 & 440 & 440 & 193600 & 23 \\
\hline Juli & 1.736 & 6.724 & -4.988 & 4988 & 24880144 & 287 \\
\hline Agustus & 3.320 & 3.011 & 309 & 309 & 95481 & 9 \\
\hline September & 3.749 & 2.901 & 848 & 848 & 719104 & 23 \\
\hline Oktober & 4.212 & 2.631 & 1.581 & 1581 & 2499561 & 38 \\
\hline November & 2.848 & 2.152 & 696 & 696 & 484416 & 24 \\
\hline Desember & 2.561 & 4.011 & -1450 & 1450 & 2102500 & 57 \\
\hline Jumlah & & & & 14171 & 34555453 & 577 \\
\hline Rata-Rata & & & & 1181 & 2879621 & 48 \\
\hline
\end{tabular}

Sumber: Hasil Pengolahan Data (2018)

Keterangan : Nilai Uji Kesalahan adalah Hasil Pembulatan

Berdasarkan Tabel 6 yang merupakan hasil perhitungan Uji Kesalahan Permalan Pegunjung dengan metode Moving Average pada Tahun 2016 diperoleh hasil uji kesalahan peramalan rata - rata nilai MAD sebesar 1181 dan nilai MSE sebesar 2879621. Untuk MAPE digunakan interpretasi nilai MAPE yang disebutkan oleh Heizer dan Render dengan nilai MAPE sebesar 48\% peramalan dapat dikategorikan sebagai peramalan yang layak.

Selanjutnya adalah hasil uji kesalahan metode analisis Moving Average 3 bulanan menggunakan data kunjungan wisatawan ke Ciwangun Indah Camp tahun 2017 yang secara lengkap dapat dilihat pada tabel sebagai berikut:

Tabel 7. Uji Kesalahan Permalan Pegunjung Ciwangun Indah Camp Menggunakan Metode Moving Average 3 Bulanan Tahun 2017

\begin{tabular}{|c|c|c|c|c|c|c|}
\hline Bulan & $\begin{array}{c}\text { Hasil } \\
\text { Peramalan }\end{array}$ & $\begin{array}{c}\text { Jumlah } \\
\text { Pengunjung }\end{array}$ & AE & MAD & MSE & $\begin{array}{c}\text { MAPE } \\
\text { (\%) }\end{array}$ \\
\hline Januari & 3715 & 2931 & 784 & 784 & 614656 & 21 \\
\hline Februari & 2233 & 3293 & -1060 & 1060 & 1123600 & 47 \\
\hline
\end{tabular}




\begin{tabular}{|c|c|c|c|c|c|c|}
\hline Maret & 1771 & 3320 & -1549 & 1549 & 2399401 & 87 \\
\hline April & 2247 & 2573 & -326 & 326 & 106276 & 15 \\
\hline Mei & 2026 & 2084 & -58 & 58 & 3364 & 3 \\
\hline Juni & 2689 & 2081 & 608 & 608 & 369664 & 23 \\
\hline Juli & 3964 & 2321 & 1643 & 1643 & 2699449 & 41 \\
\hline Agustus & 1561 & 2893 & -1332 & 1332 & 1774224 & 85 \\
\hline September & 3021 & 2738 & 283 & 283 & 80089 & 9 \\
\hline Oktober & 3123 & 2849 & 274 & 274 & 75076 & 9 \\
\hline November & 3875 & 2568 & 1307 & 1307 & 1708249 & 34 \\
\hline Desember & 4902 & 3340 & 1562 & 1562 & 2439844 & 32 \\
\cline { 1 - 6 } Jumlah & & & $\mathbf{1 0 7 8 6}$ & $\mathbf{1 3 3 9 3 8 9 2}$ & $\mathbf{4 0 6}$ \\
\cline { 1 - 4 } & & & $\mathbf{8 9 9}$ & $\mathbf{1 1 1 6 1 5 8}$ & $\mathbf{3 4}$ \\
\hline Rata-Rata & & & &
\end{tabular}

Sumber: Hasil Pengolahan Data (2018)

Keterangan : Nilai Uji Kesalahan adalah Hasil Pembulatan

Berdasarkan Tabel 7 yang merupakan hasil perhitungan Uji Kesalahan Permalan Pegunjung dengan metode Moving Average pada Tahun 2017 diperoleh hasil uji kesalahan peramalan rata - rata nilai MAD sebesar 889 dan nilai MSE sebesar 1116158. Untuk MAPE digunakan interpretasi nilai MAPE yang disebutkan oleh Heizer dan Render dengan nilai MAPE sebesar $34 \%$ peramalan dapat dikategorikan sebagai peramalan yang layak.

Selanjutnya adalah hasil uji kesalahan metode analisis Exponential Smoothing menggunakan data kunjungan wisatawan ke Ciwangun Indah Camp tahun 2016 yang secara lengkap dapat dilihat pada tabel sebagai berikut:

Tabel 8

Uji Kesalahan Peramalan Pegunjung Ciwangun Indah Camp Menggunakan Exponential Smoothing Tahun 2016

\begin{tabular}{|c|c|c|c|c|c|c|}
\hline Bulan & $\begin{array}{c}\text { Hasil } \\
\text { Peramalan }\end{array}$ & $\begin{array}{c}\text { Jumlah } \\
\text { Pengunjung }\end{array}$ & AE & MAD & MSE & MAPE (\%) \\
\hline Januari & 2851 & 3544 & -693 & 693 & 480249 & 24 \\
\hline Februari & 2955 & 1867 & 1088 & 1088 & 1183744 & 37 \\
\hline Maret & 2792 & 2157 & 635 & 635 & 403225 & 23 \\
\hline April & 2697 & 1975 & 722 & 722 & 521284 & 27 \\
\hline Mei & 2589 & 1723 & 1136 & 1136 & 1290496 & 44 \\
\hline Juni & 2466 & 1512 & 954 & 954 & 910116 & 39 \\
\hline Juli & 2323 & 6724 & -4.401 & 4401 & 19368801 & 189 \\
\hline Agustus & 2983 & 3011 & -28 & 28 & 784 & 0,9 \\
\hline September & 2942 & 2901 & 41 & 41 & 1681 & 1 \\
\hline Oktober & 2936 & 2631 & 305 & 305 & 93025 & 10 \\
\hline November & 2863 & 2152 & 711 & 711 & 505521 & 25 \\
\hline Desember & 2756 & 4011 & -1255 & 1255 & 1575025 & 49 \\
\hline Jumlah & & & $\mathbf{1 1 9 6 9}$ & $\mathbf{2 6 3 3 3 9 5 1}$ & $\mathbf{4 6 9}$ \\
\hline Rata-Rata & & & $\mathbf{9 9 7}$ & $\mathbf{2 1 9 4 4 9 6}$ & $\mathbf{3 9}$ \\
\hline Sumber: Hasinnnnyynnn
\end{tabular}

Sumber: Hasil Pengolahan Data (2018)

Keterangan : Nilai Uji Kesalahan adalah Hasil Pembulatan

Berdasarkan Tabel 8 yang merupakan hasil perhitungan Uji Kesalahan Permalan Pegunjung dengan metode Exponential Smoothing pada Tahun 2016 diperoleh hasil uji kesalahan peramalan rata - rata nilai MAD sebesar 997 dan nilai MSE sebesar 2194496. Untuk MAPE digunakan interpretasi nilai MAPE yang disebutkan oleh Heizer dan Render dengan nilai MAPE sebesar $39 \%$ peramalan dapat dikategorikan sebagai peramalan yang layak.

Selanjutnya adalah hasil uji kesalahan metode analisis Exponential Smoothing menggunakan data kunjungan wisatawan ke Ciwangun Indah Camp tahun 2017 yang secara lengkap dapat dilihat pada tabel sebagai berikut: 
Tabel 9. Uji Kesalahan Permalan Pegunjung Ciwangun Indah Camp Menggunakan Exponential Smoothing Tahun 2017

\begin{tabular}{|l|c|c|c|c|c|c|}
\hline Bulan & $\begin{array}{c}\text { Hasil } \\
\text { Peramalan }\end{array}$ & $\begin{array}{c}\text { Jumlah } \\
\text { Pengunjung }\end{array}$ & AE & MAD & MSE & MAPE (\%) \\
\hline Januari & 2927 & 3715 & -788 & 788 & 620944 & 27 \\
\hline Februari & 3045 & 2233 & 812 & 812 & 659344 & 27 \\
\hline Maret & 2923 & 1771 & 1152 & 1152 & 1327104 & $\mathbf{5 3}$ \\
\hline April & 2750 & 2247 & 503 & 503 & 253009 & 18 \\
\hline Mei & 2675 & 2026 & 649 & 649 & 421201 & 24 \\
\hline Juni & 2578 & 2689 & -111 & 111 & 12321 & 4 \\
\hline Juli & 2595 & 3964 & -1369 & 1369 & 1874161 & 53 \\
\hline Agustus & 2800 & 1561 & 1239 & 1239 & 1535121 & 79 \\
\hline September & 2614 & 3021 & -407 & 407 & 165649 & 16 \\
\hline Oktober & 2675 & 3123 & -448 & 448 & 200704 & 17 \\
\hline November & 2742 & 3875 & -1133 & 1133 & 1283689 & 42 \\
\hline Desember & 2912 & 4902 & -1990 & 1990 & 3960100 & 68 \\
\hline Jumlah & & & $\mathbf{1 0 6 0 1}$ & $\mathbf{1 2 3 1 3 3 4 7}$ & $\mathbf{4 2 8}$ \\
\cline { 1 - 5 } Rata-Rata & & & $\mathbf{8 8 3}$ & $\mathbf{1 0 2 6 1 1 2}$ & $\mathbf{3 6}$ \\
\hline
\end{tabular}

Sumber: Hasil Pengolahan Data (2018)

Keterangan : Nilai peramalan adalah hasil pembulatan.

Berdasarkan Tabel 9 yang merupakan hasil perhitungan Uji Kesalahan Permalan Pegunjung dengan metode Exponential Smoothing pada Tahun 2017 diperoleh hasil uji kesalahan peramalan rata - rata nilai MAD sebesar 883 daan nilai MSE sebesar 1026112. Untuk MAPE digunakan interpretasi nilai MAPE yang disebutkan oleh Heizer dan Render dengan nilai MAPE sebesar $36 \%$ peramalan dapat dikategorikan sebagai peramalan yang layak.

\section{Pemilihan Metode Peramalan}

Berdasarkan hasil uji kesalahan yang dilakukan pada kedua metode analisis permalan Moving Average dan Exponential Smoothing yang telah dilakukan, maka dilakukan perbandingan untuk mengetahui malat analisis mana yang paling tepat dan sesuai untuk diterapkan di Cieangun Indah Camp, dimana hasil perbandingan tersebut secara lengkap dapat dilihat pada tabel sebagai berikut:

Tabel 10. Uji Kesalahan Untuk Masing - Masing Metode Peramalan

\begin{tabular}{|c|c|c|c|c|}
\hline Metode peramalan & Tahun & $\begin{array}{c}\text { Rata-Rata } \\
\text { MAD }\end{array}$ & $\begin{array}{c}\text { Rata-Rata } \\
\text { MSE }\end{array}$ & Rata-Rata MAPE(\% \\
\hline \multirow[t]{2}{*}{ Moving Average 3 Bulanan } & 2016 & 1181 & 2879621 & 48 \\
\hline & 2017 & 899 & 808201 & 34 \\
\hline Total MAPE & & & & 82 \\
\hline \multirow[t]{2}{*}{ Pemulusan Exponential $\alpha=0,15$} & 2016 & 997 & 2194496 & 39 \\
\hline & 2017 & 883 & 1026112 & 36 \\
\hline Total MAPE & & & & 75 \\
\hline
\end{tabular}

Sumber : Hasil Pengolahan data 2018

Berdasarkan uji kesalahan peramalan, metode peramalan terpilih untuk diterapkan pada Ciwangun Indah Camp adalah Metode Exponential Smoothing. Perhitungan peramalan pengunjung Ciwangun Indah Camp dengan Metode tersebut dilakukan terhadap dua periode yakni tahun 2016 dan tahun 2017.
Melalui hasil peramalan pengunjung menggunakan metode Exponential Smoothing dapat kita ketahui jumlah pengunjung rata-rata dalam satu tahun, jumlah pengunjung tertinggi dan jumlah pengunjung terendah. Hasil peramalan pada tahun 2016 dan tahun 2017 diharapkan mampu menjadi gambaran bagi pihak destinasi wisata dalam memprediksi jumlah rata-rata 
pengunjung perbulan dalam satu tahun pada tahun berikutnya, serta menjadi dasar penyusunan rencana kerja destinasi wisata pada tahun 2018. Pihak Ciwangun Indah Camp dapat menjadikan hasil peramalan pengunjung periode 2016 dan 2017 sebagai bahan evaluasi untuk tahun 2018. Hasil perhitungan peramalan pengunjung Ciwangun Indah Camp dengan metode Exponential Smoothing diperoleh hasil peramalan untuk rata rata pengunjung perbulan pada tahun 2016 sebesar 2767 orang sedangkan pada tahun 2017 sebesar 2770 orang, dengan presentasi kenaikan pengunjung sebesar $0,1 \%$.

Melalui hasil peramalan tersebut dapat kita lihat bahwa jumlah rata-rata peramalan pengunjung perbulan dengan metode Exponential Smoothing dari tahun 2016 ke tahun 2017 mengalami kenaikan, kondisi tersebut dapat dijadikan sebagai bahan evaluasi bagi pihak Ciwangun Indah Camp agar pada tahun 2018 lebih memaksimalkan kawasan wisatanya seperti meningkatkan pelayanan, menambah wahana, melengkapi fasilitas, mengadakan program atau event-event tertentu baik tahunan maupun bulanan dan lainya, hal tersebut dilakukan sebagai upaya dalam mendukung peningkatan pengunjung yang lebih banyak.

\section{KESIMPULAN DAN REKOMENDASI}

Berdasarkan hasil perbandingan peramalan, diketahui bahwa hasil perhitungan dengan metode Exponential Smoothing menjadi metode peramalan yang lebih baik dan lebih cocok diterapkan di Ciwangun Indah Camp dibandingkan dengan metode Moving Average karena memiliki tingkat kesalahan lebih rendah. Adapun tingkat kesalahan peramalan MAD (Mean Absolute Deviation) sebesar 997, MSE (Mean Square Error) sebesar 2194496 dan MAPE (Mean Percentage Average Error) sebesar 39\% untuk tahun 2016 dan MAD (Mean Absolute Deviation) sebesar 883, MSE (Mean Square Error) sebesar 1026112 dan MAPE (Mean Percentage Average Error) sebesar 36\% untuk tahun 2017.

Dalam peramalan khususnya dalam meramalkan jumlah kunjungan hendaknya Ciwangun Indah Camp tidak hanya menggunakan satu metode peramalan, tetapi lebih dari satu metode untuk mengetahui metode mana yang paling tepat. Ciwangun Indah Camp sebaiknya meramalkan tingkat kunjungan dengan metode peramalan Exponential Smoothing karena dari hasil perhitungan memiliki tingkat kesalahan paling rendah dibandingkan metode Moving Average.

\section{DAFTAR PUSTAKA}

Heizer, J., \& Render, B. (2009). Manajemen Operasi. Jakarta: Salemba Empat.

Heizer, J., \& Render, B. (2015). Manajemen Operasi : Manajemen Keberlangsungan dan Rantai Pasokan (11th ed.). Jakarta: Salemba Empat.

Rusdiana. (2014). Manajemen Operasi. (B. A. Saebani, Ed.). Bandung: CV Pustaka Setia.

Sofyan, D. K. (2013). Perencanaan dan Pengendalian Produksi (1st ed.). Yogyakarta: Graha Ilmu.

Syahputra, R. D., Suharyono, \& Supriono. (2018). Peramalan Penjualan Jasa Freight Forwarding Dengan Metode Single Moving Averages , Exponential Smoothing Dan Weighted Moving Averages ( Studi Kasus Pada Pt Anugerah Tangkas Transportindo, Jakarta ). Jurnal Administrasi Bisnis, 55(2), 113-121.

\section{BIODATA PENULIS}

${ }^{1}$ Jordi Rachmat Hakeem, Lahir di Jakarta 26 Juli 1996. Menyelesaikan pendidikan dasar di SDN 5 Imbanagara Raya Ciamis (2002 - 2008$)$, kemudian menyelesaikan pendidikan sekolah menengah di SMP Terpadu Al-Hasan Ciamis ( 2008 - 2011 ) dan menyelesaikan pendidikan sekolah atas diSMKN 1 Ciamis ( $2011-2014$ ). Kegiataan saat ini adalah sebagai mahasiswa tingkat akhir di Manajemen Pariwisata STP ARS Internasional.

${ }^{2}$ Rahmat Priyanto, Lahir di Cilacap tahun 1988, menyelesaikan Pendidikan Strata 1 pada tahun 2013 di STP ARS internasional jurusan Manajemen Pariwisata, kemudian menyelesaikan pendidikan Strata 2 pada tahun 2016 di Magister Management Binsa Sarana Informatika. Kegiatan saat ini aktif sebagai pengajar di STP ARS Internasional. 